\section{SF 907}

\section{U57}

Copy 1

\section{PROCEEDINGS AND REPORT}

OF A:

\title{
BOARD OF OFFICERS
}

APPOINTED

BI PAR. 9, S. O. No. 71, HD. QRS. OF THE ARMY, A. G. O., APRIL 5, 1878, TO EXAMINE ANI REPORT

UPON CERTAIN PATTERNS OF.

\section{HORSE AND NULE SHOES.}

U.S. Eoard to examine horse and mule

WASHINGTON : GOVERNMENT PRINTING OFFICE. 1879 . 


$$
\text { SF } 907
$$




\section{R E P O R T}

\section{OF THE \\ BOARD TO EXAMINE HORSE AND MULE SHOES.}

War Departinent, Quarterifaster-General's OFFICE, Washington, D. C., December 17, 1878.

Under the anthority of the honorable the Secretary of War, the subjoined proceedings and report of a Board of Officers appointed by paragraph 9, Special Orders No. 71, Headquarters of the Army, Adjutant-General's Office, dated April 5, 1878, to examine and report upon certain patterns of horse and mule shoes, submitted to it by this office, is published for the information of offcers of the Army.

$$
\begin{aligned}
& \text { M. C. MEIGS, } \\
& \text { Quartermaster-General, Bet. MIaj. Gen., U.S. A. }
\end{aligned}
$$

Washington, D. C., August 1, 1878.

GENERAL: I have the honor to transmit proceedings of a Board of Officers to examine and report upon "certain patterns of horse and mule shoes" (submitted by the Quartermaster General of the Army), convened by Special Order No. 71, paragraph 9, dated War Department, Adjutant-General's Office, Washington, April $\tilde{5}, 1878$.

I am, rery respectfully, your obedient servant, E. B. HUBBARD,

First Lieutenant Second Artillery, Recorder.

The Adjutant-General U. S. Ariry, Washington, D. C. 
[First indorsement.]

AdJutant-General's OFFICE,

Trashington, August 13, 1878.

Respectfully referred to the Quartermaster-General.

E. D. TOWNSEND, Adjutant-General.

[Second indorsement.]

WAR DEPARTMENT, QUARTERMASTER-GENERAL'S OFFICE, Washington, September 23, 1878.

Respectfully returned to the Arjutant-General of the Army, with the recommendation that 1,000 copies of the report and papers in full be printed and distributed to officers of the Army, and that such order, if any, be issued as may be needed.

\section{C. MEIGS,}

Quartermaster-General, Bvt. Maj. Gen., U. S. A.

4463, Q. M. G. O., 1878; filed with 1174 of 1877 (9 inclosures).

[Third indorsement.]

ADJUTANT-GENERAL'S OFFICE,

Washington, Sept. 25, 1878.

Respectfully submitted to the Secretary of War, with papers on which the Board was comvenel.

E. D. TOWNSEND, Arljutant-General.

[Fourth indorsement.]

The recommentation of the Quartermaster-General is approred.

By order of the Secretary of War.

H. T. CROSBY,

Chief Clerk.

IVAR Department, October 1, 1878. 
[Fifth indorsement.]

\title{
ADJutaNT-GmenaL'S OFFICE, Tashington, October 4, 1878.
}

Respectfully returned to the Quartermaster-General, inviting attention to action of the secretary of War indorsed hereon.

\author{
E. D. TOWNSEND, \\ Adjutant-General.
}

Proceedings of a Board of Officers convened at Wrashington, D. C., pursuant to the following special oriter:

Special Order's No. 71.

Headquarters of the Army, ADJTTANT-GENERAL's OFFICE, Whishington, April 5, 1878.

[Extract.]

9. With the approval of the Secretary of Wrar, a Board of Officers, to consist of Capt. F. B. Hanilton, Second Artillery; Capt. J. G. Ramsay, Second Artillery; First Lient. E. B. Hubbard, Second Artillery, will assemble in this eity on the 11th day of April, 1878, or as soon thereafter as practicable, for the purpose of examining and reporting upon certain patterns of "luerse and mule shoes," which have been brought to the attention of the Quartermaster-General's Office, with a view to their adontion for Amy nse, and such other patterus as may be presented at said olifes during the existence of the Board, or that the Quarternaster-General may desire to submit, other than the patterus adopted for use in the Army by General Orlers No. $i$, Frbruary 2, 1=76, fiom the War Dejartment, Adjutant-Greneral's Office.

The junior wember will aet as recorder.

By command of General sherman :

E. D. TOWNSEND, Adjutant-General.

Official :

L. H. Pelouze, dssistant Adjutant-General. 


\section{TIASHINGTON, D. C., April 11, 187s-12 o'clock m.}

The Board met, pursuant to the foregoing order, at the office of the Quartermaster-General. Present: Capt. F. B. Hamilton, Second Artillery; Capt. J. G. Ramsay, Second Artillery; First Lieut. E. B. Hubbard, Second Artillery.

After organization the Board adjourned to April 12, at 11 o'clock a. m., to give opportunity to the Quartermaster-General to present to them specimens of horse and mule shoes ordered for examination and report.

\section{E. B. HUBBARD,}

First Lieutenant Second Artillery, Recorder.

\section{Washington, D. C., April 12, 1878-11 o'clock a. $\mathrm{m}$.}

The Board met pursuant to the foregoing adjourmment. Present, all the members.

There being no business before it, as no shoes have yet been submitted by the Quartermaster-General, the Board then, at 3.30 o'clock p. m., adjourned to meet tomorrow, the 13th instant, at 11 o'clock a. m.

E. B. HUBBARD, First Lieutenant Second Artillery, Recorder.

\section{WAsHINGTON, D. C., April 13, 1878-11 o'clock a. m.}

The Board met pursuant to adjournment. Present, all the members.

The Quartermaster-General not having the samples of horse aud mule shoes ready for presentation, the Board then, at $2.30 \mathrm{p} . \mathrm{m}$., adjourned to meet Monday, the $15 \mathrm{th}$. instant, at 12 o'clock $\mathrm{m}$.

\section{E. B. HUBBARD,}

First Lieutenant Second Artillery, Recorder. 
Washington, D. C., April 15, 1878.

The Board met pursuant to adjourmment. Present, all the members.

A letter dated April 12, and received by the Board April 15, 1878, from the Quartermaster-General United States Army, together with the following enumerated samples of horse and mule shoes:

1. Howard's Patent Horse shoe. Two samples, and the papers 223 and 1281, Q. M. G. O. 1878, relating thereto.

2. Kiernan's Patent Horse and Mule shoes. Trentythree samples, and the papers 4024 (four inclosures) and 5685, Q. 1I. G. O., 1877 and 187, Q. M. G. O., 1873 (one inclosure), relating thereto.

3. Shoenberger "Roadster" Pattern Horse shoes. Ten samples, and the papers $15 \pm 6$, Q. MI. G. O., 1878 (one inclosure), relating thereto.

4. Seeley Horse shoes, manufactured by the Rhode Island Horse Shoe Company and supplied by the Goodenough Horse Shoe Company, New York City. Two samples, and the papers 4362 (one enclosure), and 5077, Q. M. G. O., 1877, and memorandum report of Captain Rockwell, depot quartermaster in this city, relative to the horse shoes used on the horses of the Washington and Georgetown Railroad.

For copies of these letters and report above mentioned, see pages 29 to 53 , inclusive, of file marked $\mathrm{A}$, accompanying this report.

The foregoing samples of horse and mule shoes being before the Board, the Board, in view of the restrictions in the order of their convocation, addressed by their President a communication to the Quartermaster-General United States Army requesting that they be fumished a copy of the proceeding's of the Board of Officers held in Philadelphia, and referred to in General Orders No. 7, 1876, Adjutant-General's Office, so far as it relates to the discussion of horse and mule shoes.

Pending the receipt of this communication the Board then, at 4 o'clock p. m. , adjourned to meet to-morrow, the 16th instant, at 11 o'clock a. $\mathrm{m}$.

$$
\text { E. B. HUBBARD, }
$$

First Lieutenant Second Artillery, Recorder. 


\section{Washington, D. C., April 16, 1878-11 o'clock a. m.}

The Board met pursuant to adjournment. Present, all the members.

The Board then proceeded to the examination of the Howard Malleable and Cast-Iron Shoe, and made a practical test of the shoeing of horses with these shoes.

The Board also practically tested the malleability of the cast iron contained in them with the following result: Uncler the hammer only a slight change of form was found could be effected without producing fracture. In the vise it was found the heels could be compressed or expanded to a considerable extent without fracture, but in a compression of the heels was found to alter the plane of the shoe somewhat, and owing to its width, and the yieloing being confined to the toe as an axis of compression, to lessen the width in order to fit a foot would likely canse the heels of the shoe to interfere with the frog.

In other words, the shoe as presented cannot be well made to fit the foot and to be of practicable use. Shoes of this pattern would have to be made of sizes numerous enough to conform to the raried forms and sizes of the hoofs (properly prepared for the shoeing) of any animals.

No mule-shoes of this pattern have been submitted to the Board. The Board found at the corral of the Quartermaster's Department specimens of this shoe that had been worn by animals in daily use. Though no exact date was or could be then obtained as to the length of time they had been on the animals, they were well worn, and still showed the tarred rope as retaining its position in the shoe. Its merits as to preventing shock, sc., were much decreased by its having become dry and hard with gravel, sand, \&c., gromed into it by travel. One shoe examined had worn to a feather thimness on one side, while the other side of the same shoe retained nearly its original thickness; this effect may have been produced by the horse's peculiar action. A shoe which had been compressed (and slightly cracked, though not broken, in 
shoeing a horse) was seen. It had been on the animal but one day when one-half was lost, carrying with it the rope of the whole shoe, and leaving on the animal but the other half of the cast-iron shell, which, in that condition, was much worse on the horse than halt of a simple horseshoe would have been. The shoe as tested under the hammer showed that manner of altering its form conld not safely be resorted to.

It seems evilent that to make any safe change in the form of this shoe, and so far as we were enabled to do it from means at hand, even this was confined to compressing and expanding the heels, that a rise is necessary or some similarly acting tool. In its present form we believe that it would be rery diffienlt to put it on horses muless they lare good, perfect hoofs.

The animals on which the Board experimented had almost exceptionally fine feet. The nail-holes in the samples of shoes before the Board are all so made that difficulty arises in making the shoes hold, the nail not taking firm enough hold on the hoof.

The Board then, at \pm o'clock $1 \%$. m., adjourned to meet to-morrow, the 17 th instant, at 11 o'clock a. 11 .

E. B. HUBBARD, First Lieutenant Second Artillery, Recorder.

\section{Washington, D. C., April 17, 1878.}

The Board met pursuant to the foregoing arljournment. Present, all the members.

The Board, atter discussion mon the Howarl Shoe, proceederl to the oftice of the president of the Washington and Georgetomn Railioud, they having been informed that some of the patented shoes presented to them had been in use on the horses of that railroad, and believing that such experience would be of great ralue to them. (It is interesting in this connection to note the fact that the route of this roal is pared with cobble-stones, i. e., between the rails where the horses travel.) The president, Mr. Hurt, accompanied the Board to the shoeing- 
shops of his company. Stated to them that none of the shoes were now used on his road, but gave their experience in the use of the Goodenough and Seeley systems.

The former, after long trial by them, had been utterly discarded, as had the latter after shorter trial. The company, howerer, gave up the Seeley Shoe, not from any positive refects so much as exorbitant cost, an increase of 25 per cent. having recently been demanded by the manufacturers.

The Board then, at 4 o'clock p. m., adjonrned to meet to-morrow, the 18th instant, at 11 o'clock a. m.

E. B. HUBBARD,

First Lieutenant Second Artillery, Recorder.

Washington, D. C., April 18, 1878.

The Board met pursuant to adjournment. Present, all the members.

The Board, after some discussion upon the rarious shoes before it, proceeded to the smithery of the Metropolitan street railroad. This company use the Seeley Shoe exclusively, and on their route the animals arerage seventeeu miles daily orer a nearly continuous cobblestone roadway.

The Seeley Shoe used by them is the Plane pattern (4362, Q. M. G. O., 1875). The superintendent of this railway showed the Board the shoes in use, and those worn out, and from his practical experience with it since last July on more than 200 horses, gives it his most unqualified approval. Their method is to put on the shoe cold, with all changes made except calks and toes in same state; they need only turning up at the heel and welding on steel toes to make a winter shoe. No toes or ealks are used save in winter service, \&c. All old shoes examined gave evidence of very even wear and excellent lasting quality, and are so put on as to allow "frog pressure." The shoes used by this company hare shown uniformly good quality of material. The only. 
objection urged by the railroar company to the shoe is a recent increase of 25 per cent. in their cost.

The Board then, at 3 o'clock p. m., adjourned to meet to-morrow, the 19 th instant, at 11 o'elock a. m.

E. B. HUBBARD,

First Lieutenant Second Artillery, Recorder.

\author{
WAsHIfGTON, D. C., \\ April 19, 1878-11 o'clock a. m.
}

The Board met pursuant to adjournment. Present, all the members.

The Board then proceeded to the examination and criticism of the Kiernan Shoe. This shoe is a continuous calk of steel, as per pattern and letters in Q. M. G. O., Nos. 4024 (four inclosures), 5685 (1877), 187 (1878). Of the samples submitted, all are handmade cast-steel shoes. It is proposed by Kiernan to have them of crucible steel, at a cost of 13 cents per pound.

Pending continued practical tests of the Howard Shoe, and the shoeing of some animals with the Kiernan Shoe from samples of shoes furnished the depot quartermaster in this city (the Board only haring been furnished a single sample of the Seeler Cast-steel Winter Shoe, wrote a communication to the Quartermaster-General for two sets of said shoes). The Board then, at 2.30 o'elock p. m., adjourned, to meet Monday, the $22 d$ instant, at 11 o'clock a. m.

E. B. HUBBARD,

First Lientenant Second Artillery, Recorder.

\author{
WASHiNGtor, D. C., \\ April 22, 1878-11 o'clock a. m.
}

The Board met pursuant to adjourmment. Present, all the members.

The Board continued the examination of the Kiernan Shoe. The following papers relating to the Howard Shoe were received from the Quartermaster-General 
and considered by the Board, viz: Lettex from Marcus J. Wright \& Co., Saint Louis, Wo., to the QuartermasterGeneral, dated Jannary 19, 187s, stating advantages they claim for the Howard Improved Horseshoe; letter from Capt. A. F. Rockwell, A. Q. M., depot quartermaster, Washington, D. C., to the Duartermastex-General, dated April 17, 1878, giving results of trial of the Howard Shoe and his opinion of its merits; letter from James Bushman, veterinary surgeon at quartermaster's depot, to Captain Rockwell, A. Q. M., in charge, dated April 15, 1578, giving results of trial of some Howard Patent Horseshoes, and making criticisms on the same.

For copies of the above-mentioned letters and reports, see jages 13,17 , and 19 of file marked $A$, accompanying this report.

The Board not having received any reply to their communication to the Quartemaster-General in regard to the Seeley Cast-steel Winter Shoes, nor received the shoes, adjonmed to meet at 11 oclock a m. to-morrow, the 23 d instant.

\title{
E. B. HUBBARD,
}

First Lieutenant Second Artillery, Recorder.

\author{
WASHINGTON, D. C., \\ April 23, $1878-11$ o'clock a. 11 .
}

The Board met pursuant to adjournment. Present, all the members.

The Board not having yet been furnished with the Seeley Shoes from the Quartermaster's Department, visited the Quartermaster-Genemal's Office, and made arrangements to have those shoes sent to Captain Hamilton at the arsenal, to be put on horses there. The Board also asked for a cony of the report of Col. H. C. Hodges, deputy quartermaster-general.

'The Board then, at 3 o'clock p. m., adjomrned (pending trial of shoes already on animals nuller observations of the Board) to meet Friday, May 3, at 12 o'clock m.

$$
\text { E. B. HUBBARD, }
$$

First Lieutenant Second Artillery, Recorder. 


\section{Wasmington, D. C., May $3,1878-12$ o'clock m.}

The Board met, pursuant to adjournment of the $23 \mathrm{~d}$ ultimo, at 12 o'clock $\mathrm{m}$. Present, all the members.

The Board then proceeded with the diseussion of the Kiernan Shoe. The shoes of this pattern used by the Board in their experiments were received from the depot quartermaster in Washington. The shoes of two animals shod with these shoes were examined after ten days' use. The continuous calk, the vital principle of the shoe, had in nearly all these shoes been worn nearly down in that short time.

Abont a keg of these shoes have been nsed by the depot quartermaster, and the testimony of those in charge and the smith's is, that this continuous calk has only lasted from ten to twelve days!

This Board, in view of the high testimonials submitted for this shoe, do not feel justified in its condemmation. The samples furnished the Board did not meet the claims of the inventor, and did not wear better than a common shoe, nor do we find any other adrantages as claimed. The form of this shoe can only be changed when the shoe is "cherry redl."

If, as is claimed by the inventor, that the toe of this shoe has to be hardened (tempered) mpon application, it fails in the great desideratum of a field-shoe, cold application. Owing to the high testimonials already referred to, the Board would respectfully recommend further trial (under specific directions fron the inventor, as to hardening, \&e.), at some appropriate repot.

The Board are willing to think (from examination of shoes of this pattern from Saint Louis depot, which were labeled and said to have undergone certain long and hard usage, anil stood so much better than aceompanying competitive specimens) that possibly the shoes of this pattern used by the Qnartermaster's Department in this city had not been hardened to the extent desired by the inventor.

The Board then, at $3.30 \mathrm{p}$. m., arljourned to meet tomorrow, the 4th instant, at 10.30 o'elock a. $\mathrm{m}$.

E. B. HUBBARD,

First Lieutenant Second Artillery, Recorder. 
WAshington, D. C., May 4, 1878-10.30 a. m.

The Board met pursuant to adjournment. Present, all the members.

The Board, continuing their discussion of the business before it, are of the opinion, in regard to the Howard Patent Horse shoe, that their durability, when put on without change of original form, is unquestioned. While, as is claimed, the adrantage in not "pricking" the feet when shod with this shoe is gained, a corresponding disadvantage is apparent in the insecurity of hold.

We are not satisfied, from such trials as were in our power to make, that this shoe is useful when widened or compressed (and these are the only changes it arlmits of), and hence do not deem it a desirable shoe for frontier service.

The fact is, the shoe is only adapted to a foot that the sizes perfectly fit, and to a hoof not splintered nor full of nail-holes, as is frequently the case.

The shoe admits of no other change than a very slight widening or a similar compression; and these changes are made by the vise (the inventors state they are preparing a machine for its change of form) at the risk of cracking the shoe, when it, being of cast iron, is useless. No information concerning the cost of these shoes (and it seems quite an important consideration) is before the Board. Ten difterent sizes of shoes are proposed to be furnished by this company (fire for romel and fire for elongated feet).

\section{SHOENBERGER "ROADSTER."}

The Shoenberger "Roadster" Shoe is a lighter pattern than the shoe of this company recommended by the Philadelphia Board for Army use.

\section{SEELEY "CAST-STEEL WINTER SHOE."}

The "Seeley Cast-steel Winter Shoe" was not tested, the samples finmished being too small for any available animals, and the season not being appropriate. 


\section{SEELEY PLAIN SHOE.}

The Seeley Plain Shoe has receired the elose attention of the Board, and they have received much practical information concerning it from varions sources, and all of a commendatory character. The quality of all examined and heard from has been mitomly good. This shoe possesses the prime adrantage of being applied cold; has no peculiarities of form other than being a most shapely and weil made article.

The Board give this shoe their unqualified approval, and respectfully call attention of the department to its great simplicity, durability and facile application. They believe it to be a capital shoe for Army use. The Board, in this connection, of course, anticipate the present high standard of iron being maintained.

The Board then (pending the receipt of other shoes from the Quartermaster-General) adjourned at 12.30 o'clock p. m. to meet at the call of the President.

E. B. HUBBARD, First Lieutenant Second Artillery, Recorder.

Washington, D. C., May 21, 1878.

The Board met pursuant to adjoumment, at the call of the President, at 12 o'clock m. Present, all the members.

The President then laid before the Board two letters of dates respectively May 16 and May 20, 1878, received from the Quartermaster-General (for colvies of these letters see pages 62 and 63 , of file marked A accompanying this report) inclosing papers marked 2260 Quartermaster-General's Office, received April 21, 1878, two inclosures $(2,2260$ and 3, 2260) and 2603 QuartermasterGeneral's Oftice, received May 16, 1875, (one inclosure marked "File with 2603,1878 "), and also three sets of Henry C. McCeney's Patent Horse shoes, and one set of Mule-shoes, and twelre samples John D. Billings's Machine-rolled Horseshoes, and a sample of which made. 
There being no animals arailable for the trial of these shoes, the Board addressed by the President a letter to the Quartermaster-General, asking for animals on which to make trials of these shoes, of which the following is a copy :

WASHINGTON ARSENAL, Tashington, D. C., May 21, 1878.

SIR: I have the honor to request that faeilities be granter the Board on Horse and Mule Shoes, now in session in this city, pursuant to S. O. No. 71, Headquarters of the Army, A. G. O., April 5, $18 \pi 8$, for testing practically on government animals the varions additional patterns of shees which are now being prepared for submission to the Board.

Very respectfully, your obedient servant.

F. B. HAMILTON,

Captain Second Artillery, President of the Board.

Quartermaster-General U. S. A., Thashington, D. C.

Pending an answer to the foregoing letter, the Board then, at 3 o'clock p. m., arljourmed to meet at the call of the President.

E. B. HUBBARD, First Lieutenant Second Artillery, Recorder.

Fort McHenri, Mid., June 10, 1878.

The Poard met at the call of the President, and pursuant to the following special order:

[Special Oriter's No. 122.]

Heatquarters of time Ariry,

Adjutant General's OFFice;

Washington, Jnne 6, 1878.

[Extract.]

3. With the approval of the Secretary of War, the Board of officers appounted by paragraph 9 Special Orders No. 71, April 5, 18\%8, from this offiee, now in session in this city, is authorized to proceed to Fort McHenry, Ma., for the purpose of testing, practically, certain 
patterns of horse shoes on the horses of Light Battery A, Second Artillery, stationed at that post. On the completion of this duty the Board will resume its present station.

By command of General Sherman.

Official :

$$
\begin{aligned}
& \text { E. D. TOWNSEND, } \\
& \text { ddjutant-General. }
\end{aligned}
$$

R. C. Druni, Assistant Adjutant-General.

Present, Capt. F.B. Hamilton, Second Artillery; Capt. J. G. Ramsay, Second Artillery; First Lieut. E. B. Hubbard, Second Artillery.

The Board then proceeded to the further examination of the Howard Patent Horseshoe and also the McCeney Non-interfering Horse and Mule Shoe, and John D. Billings's Patent IIachine-rolled Horse shoe. The inventor of the latter shoe having had expressed a desire to be present at the first shoeing of horses with his shoes, and having been notified by the Quartermaster-General that the Board would meet this dar, appeared in the morning with an assortment of shoes, and a special nail with which to put them on. All the members of the Board were not then present. However, he superintended the shoeing of one horse in the presence of one member of the Board and gave the smith special instruction in regard to driving the nails, which, he said, was all he cared to speak about. He noticed that the romded part of the shoe upon which the heel is intended to rest had to be cut off to prerent interference with the frog.

The Board, after making selections of horses to be shod, and having witnessed the shoeing of some of them, adjoumed to meet from time to time, until all the shoes had had a satisfactory trial.

E. B. HUBBARD, First Lieutenant Second Artillery, Recorder.

For' MCHENRY, MD., July 16, 1878.

The Board being in session in pursuance of S. O. No. 122, paragraph 3, War Department, A. G. O., June 6,1878, submit the following additional report on the Howard

$2 \mathrm{H} \mathrm{S}$ 
Patent Horse shoe, and also their conclusions in regard to the McCeney Non-interfering Shoe, and John D. Billings's Patent Machine-rolled Horse shoes, as follows:

\section{HOWARD PATENT HORSESHOES.}

Shoes of this pattern having been one month in ordinary use (and by no means subjected to any severe test) seem nearly as new-their lasting qualities being, as before said, unquestioned. Shoes that have conformed to shape of hoofs of animals shod have proved of good and effective service ability.

This shoe, in the opinion of the Board, may well be used for draught animals at depots, but they do not regard it as applicable (with the sizes now furnished) as adaptable to either cavalry or mounted artillery.

No mule shoes of this pattern were submitted to the Board.

\section{M'CENEY SHOE:}

The Non-interfering Shoe submitted by McCeney was examined by the Board. No animals needing this treatment were available for experiment. The shoe was not practically tested. The shoe, however, combines the features of non-interfering shoes in common use, and, having an iron shoe susceptible of ehange in form, appears to be an excellent shoe for animals needing special care in their shoeing to prevent interference.

BILLINGS PATENT CONTINUOUS CALK MACHINE-ROLLED HORSESHOE.

On account of the width of the bearing surface of the shoe at the heels and the consequent interference with the frog, it was found necessary in almost every case where the shoe was applied to cut off the curred ends. Great difficulty was found in making a good clinch, the high calk interfering with the lammer. The inventor claims this difficulty can be obviated by using an Lshaped tool, but none was furnished the board and none was attainable. Especial care was taken, howerer, by the smith in fitting and clinching; yet in almost every instance of horses shod with this shoe the shoe loosened 
after short usage. It would seem that the nails, not bearing on the ground, and being at all times subject to a loosening process by the action of the shoe in twisting, climbing, and holing back, are apt to become loose. With the shoes furnished the Board, the continuous calk, the special feature of this shoe, did not have a life more than equal to a good quality of smooth shoe. The shoe when the calk is worn down becomes but a plate. In clayey ground this shoe fills and stuff's badly, and in winter it would be likely to clog easily. In cases where the shoe did not accurately fit the animal much difficulty was found in fitting the shoe on account of its peculiar form.

The shoe is not only not readily applied by the ordinary smith, but requires great pains, much time, and labor.

The Board do not regard this shoe adapted for Army purposes.

Testimonials in favor of the Howard Patent Horseshoe and of John D. Billings's Patent Machine-rolled Horseshoe fiom varions sources are appended as they were sent by the inventors to the Board. (See files B and $\mathrm{C}$, respectively.)

The Board, having completed its duties at this post, adjourned, in compliance with foregoing order, to meet at Washington, D. C., July 18, 1878.

$$
\text { E. B. HUBBARD, }
$$

First Lieutenant Second Artillery, Recorder.

Washington, D. C., July 18, 1878.

The Board met pursuant to adjournment. Present, all the members.

The Board, having completed its labors, adjourned sine die.

F. B. HAMILTON,

Captain Second Artillery, President.

J. GALES RAISAY, Captain Second Artillery.

E. B. HUBBARD, First Lieutenant Second Artillery, Recorder. 


\title{
COPIES OF LETTERS, PAPERS, ETC., REFERRED BI THE QUARTERMASTER-GENERAL, U. S. A., TO THE BOARD ON HORSE AND MULE SHOES.
}

\author{
IVAR Department, \\ Quartermasteli-General's OFFICE, \\ Washington, D. C., Aprii 12, 1878.
}

Captain: Your letter of this date, informing this office that the Board of Officers appointerl to meet in this city on the 11th instant to examine and report mpon patterns of horse and mule shoes to be submitted to it by the Quartermaster-General is now in session, is received.

I submit to the Board the following-mentioned patterns of horse and mule shoes, and papers connected therewith, now in this office:

Howard's Patent Horseshoe, two samples, and the papers 223 and 1281, Q. M. G. O., 1878, relating thereto.

Kiernan's Patent Horse and Mrule shoes, twenty-three samples, and the papers 4024 (4 inclosures) and 5685, Q. M. G. O., 1877, and 187, Q. M. G. O., 1878 (inclosure), relating thereto. This shoe was recommended for trial by First Lient. S. L. Woodward, Tenth Cavalry, A. A. Q. M. at Saint Lonis Barracks, Mo., in his annual report for the fiscal year ending June 30, $18 \% 7$.

Shoenberger \& Co.'s "Roadster" Pattern Horseshoes, ten samples, and the papers 1546 , Q. M. G. O., 1878 (1 imclosure), relating thereto.

"Seeley's" Horseshoes, manufactured by the Rhorle Island Horseshoe Company, and supplied by the Goodlenough Horseshoe Company, New York City, two samples, and the papers 4362 ( 1 inclosure), and 5077, Q. M. G. O., 1877, and memorandum report of Captain Rockwell, depot quartermaster in this city, relative to the horseshoes used on the horses of the Washington and Georgetown Railway.

The Howard Shoe is now being tried by the depot quartermasterin this city.

A small invoice of Kiernan Shoes have also been ordered shipped to the depot quartermaster in this city for trial.

These are all the patterns of horse and mule shoes, and papers 
pertaining thereto, which this office is now ready to lay before the Board for its examination and consideration.

Very respectfully, your obedient servant,

M. C. MEIGS,

Qiartermaster-General, Brt. Maj. Genl., U.S. A.

Capt. F. B. Haniltox, Second Artillery, President Board on Horse and Mrule Shoes,

Washington, D. C.

2026, Q. M. G. O., 1878, filed with 1174, Q. M. G. O, 1877 (16 inclosures).

A true copy :

J. Gales Ramsax,

Captain Second Artillery.

Note.-The letters patent in case of Howard Horseshoe is No. 200301, dated February 12, 1878.

[Marked 223 (Q. Mr. G. O., Jan'y 14), 1878.]

NORTHEAST CORNER OF Fourth AND

Market STREets, RoOM 42,

Saint Louis, January 8, 1878.

SIR: These shoes are put on cold-no fire-consequently no burning of the horse's hoofs. If wished to be expanded or contracted, do so in a vise. We have six different sizes; these herewith inclosed are No. 4 size, and will tit a good-sized hoof. The horseshoer has only to trim the hoof smooth and nail the shoes on same as ordinary shoe.

This shoe prevents a horse from slipping, forms a cushion on the ground (by the tar rope in cavity), thereby saring the horse from being stove up. The liorse on a hard road goes as easy as on a soft one; there are no heels, thus giring the natural play to the foot, which is observed in a state of nature; absence of fire prevents anything like splitting the hoof. These shoes wear longer than the ordinary shoe, are as cheap, and a firm protection to the hoof.

We have numerous testimonials from horseshoers, livery-stable men, contractors, and others, all of whom have tested the shoe and pronounce them the best they have ever tried, and do more than I claim for them.

Very respectfully,

JAMES R. HOWARD,

Inventor.

A true copy:

J. Gales Ravisay,

Captain Second Artillery. 
[Marked 415, Q. M. G. O. Rec'd Jan'y 23d, 1878.]

Sarnt Loyis, January 19, 1878.

SIR: I have the honor to acknowledge receipt of your letter of January 15, and to state that we claim the following-named advantages for the Howard Improved Horseshoe over any horseshoes now in use.

That being marle of best malleable iron, that they have more strength and malleability than any other shoe. They are put on without heat, and consequently the hoof is not injured by burning.

The rope with which they are filled, and which will wear with the iron, prevents the horse from slipping, and forms an elastic cushion, preventing tender foot, sprains, and what is known as being "stove up." They are a protection against "counter cracks" in the hoof, and do not slip or move until worn out; they are exactly level, giving play to the foot, withont contraction or irregularity. They will wear longer than the ordinary shoes, and are always ready to be put on, being fitted and sized in six different sizes, for both fore and hind feet, and will fit closely and correctly any horse not having a malformation of the hoof. Therr use in the Army would obviate the use of forges on long marches, as any man with a knife and hammer can put on or take off the shoes. We are having a number of sets of them prepared to be sent you for trial, and it is quite probable that I will visit Washington about the 1st of February, in which event I shall bring the shoes with me, and will have the honor of seeing you in person in regard to the matter.

I am entirely confident, from tests we have made of these shoes, that they are admirably suited for the Army, and that a trial of them will be quite satisfactory.

I have the honor to be, very respectfully, your obedient servant, MARCUS J. WRIGHT.

General M. C. Meigs,

Quartermaster-General, Thashington, D. C.

(Reply to 5518, Q. M. G. O., 1877.)

A true copy:

J. GaLes Ravisay,

Captain Second Artillery.

[First indorsement.]

War Departuent, QUaRTERMaster-GeNeral's OFFiCe, Washington, February 15, 1878.

Respectfully referred, by direction of the Quartermaster-General, to Capt. A. F. Rockwell, A. Q. M., U. S. A., depot quartermaster 
in this city, for trial of the horseshoes (accompanying) in use, and report as to their merits with return of this paper.

HENRY C. HODGES,

Deputy Quartermaster-General, $C$. S. A.

A true copy :

J. Gales Ranisay,

Captain Second Artillery.

[Marked (2140) Q. M. G. O. Rec'd Ap'l 17th, 1878.]

\section{Depot Quartermaster's OfFice, Washington, D. C., April 17, 1878.}

GENERAL: I have the honor to return herewith letter of Marcus J. Wright \& Co., referred to me from your office on the 15th of February last, for trial of the shoe accompanying, and to submit the following report pertaining thereto:

The shoe has had a fair trial and its merits and faults have been fully considered; I think it a good shoe for use in connection with other shoes.

The size and slape of horses' feet vary, and on some animals this shoe conld not be used, from the fact of its being too wide in the toe and shoulder, and as it could not be compressed was useless. Where the shoe fitted the hoof exactly, good service was attained, and I was surprised at their durability, which exceeded that of the ordinary shoe by about one-fourtl. On the concrete pavements of this city, it is especially useful to prevent slipping.

No shoe should in my judgment be adopted for general use that requires the foot to be fitted to the shoe. The opposite is the desideratum. I should like some of these shoes for use (with other shoes) in the blacksnith shop at this depot.

The report of the veterinary surgeon, who has given much attention to this subject, is submitted lierewith.

Very respectfully, your obedient servant,

A. F. ROCKWELL, Depot Quartermaster.

To the Quartermaster-General of the Army.

A true copy :

J. Gales Ramsay,

Captain Second Artillery.

[First indorsement.]

$$
\begin{gathered}
\text { War Departient, } \\
\text { QUartermaster-GeNeral's OFFICE, } \\
\text { Washington, April 17, } 1878 .
\end{gathered}
$$

Respectfully referred, by direction of the Quartermaster-General, to Capt. F. B. Hamilton, Second Artillery, President of the Board on Horse and Mule Shoes 1700 Penusylvania avenue, this eity, for 
consideration of the Board in eonnection with the Howard Horseshoes submitted to it for examination and report.

HENRY C. HODGES,

A true copy :

$$
\text { Deputy Quariermaster-General, U.S. A. }
$$

J. Gales RaMsay,

Captain Second Artillery.

[Marked 2140, Q. M. Gen.'s Office. Rec'd Ap'l 17th, 1878.]

Washington, D. C., April 15, 1878.

Sin: In February, 1878, some Howard Patent Horseshoes were sent to the corral for trial. They have had a fair test with other shoes; as they are cast and cannot be altered in shape, a large variety of sizes would be necessary to bring them into general use.

The small number used here have been put on horses selected because their feet fitted the shoes we had. Great care was to be exercised in this regard, for if the foot has to be made to fit the shoe, that would be a serious objection to any horseshoe. The toe-clip is too thick. They are of about equal weight with the ordinary shoe, but are wider and thicker, and consequently need more or larger nails and deeper holes. When carefully put on horses with good feet they wear well, and seem to be eminently adapted to a certain damp, slippery condition of the concrete pavements in this city. I cannot say how they may do in winter; that would have to be determined at that season. I do not know how they compare in price with other shoes; that is an important consideration.

In conclusion, I have the honor to report that whilst I do not consider the Howard Patent Horseshoe adapted to supplant the ordinary shoe, I do think they would be a useful adjunct in the blacksmith shops here.

I am, sir, yours, very respectfully,

Colonel RockweLL,

JAS. BUSHMAN,

Veterinary Surgeon.

Depot Quartermaster.

A true copy :

J. Gales RaMsay, Captain Second Artillery.

[Marked (4024) Q. M. G. O. Rec'd Sept. 13, 1877.]

Saint Louis Barracks, Mo., August 21, $187 \%$.

SIR: In complianee with instructions from your office, I have furnished samples of my improved Continuous Calk Horseshoe, and 
also some of the other manufacture, showing the difference in the wear of each, which will give an idea of the advantages to be derived from the use of my shoe.

Haring had eighteen years' practical experience as a farrẹer, I am enabled to claim the following adrantages for my shoe over all other's, viz:

1st. The shoe allows a horse to rest his weight equally on his entire surface, preventing corns, \&c., and protects and supports the coneave or pumiced sole surface of the hoof.

2d. Durability is given to the shoe by the large toe-piece, which on first application of the shoe the smith shonld harden, and thus prevent the wear of the continuous calk, the wear being alwass greater on the toe than on the quarters.

$3 d$. By use of the continuous calk, the walls of the hoof are protected while traveling over any lind of rough surface, and the bearing being on the inside of each quarter it will tend to expand contracted hoofs, and also protect the frog by allowing free expansion.

4th. For winter use the toe-piece should be beveled at the front side to form a sharp calk, and thus prevent slipping, but still have enough metal to prerent wear.

5th. By the use of my shoe cavalry going on a scout of three or four months will only be obliged to earry with them a quantity of nails, whereas now they are required to carry a supply of shoes, as it will be seen by my samples that my shoe will last a horse for four months, or at the hardest wear but four pair a year, while those of other manufacture are required to be replacesl every month. It will thus be plainly seen that by casting my shoe in steel it will repay in a very short time the small additional outlay they require.

6th. Possibly the greatest advantage that could be elaimed for my shoe is, that no matter how rongh the road may be the nails are always protected by the continnous calk, and only need replacing, say, once a month, and thus prerent a loose or casting shoe while on the march.

The samples of the shoe sent have been placed under the severest tests possible, and the result has proved entirely satisfactory. Inclosed please find letters of testimonial from parties who have had the shoe in use.

I am, sir, very respectfully, your obedient servant, JOHN KIERNAN, Chief Farrier, U. S. A.

First Lient. S. L. Woodward, Tenth Caralry, A. A. Q. M., Saint Lonis Barrack, Mo.

N. B.-The average price of these shoes, cast in Bessemer steel, will be 8 to 9 cents per pound, and are as easily applied as any other shoe. Please return the testimonials to me.

A true copy:

J. Gales Ranisay, Captain second Artillery. 
Copies of letter's testimonial.

SaINT Louis Barracks, Mo.,

September $30,1874$.

To whom it may concern :

I take pleasure in recommending to your favorable notice Mr. John Kiernan, who has for many years held the important position of chief farrier of the cavalry depot, United States Army. He is a gentleman of good eharacter and habits, and an excellent farrier and veterinary surgeon. He has invented and perfected a horseshoe which, after thorough trial at this depot, has proven to be superior to any heretofore used, and which only needs to be properly introduced and made known to insure its adoption in place of any horseshoe now in use.

B. H. GRIERSON,

Colonel Tenth Cavalry, Bvt. Maj. Gen., U. S. A.

A true copy :

J. GaLes RaMsay,

Captain Second Artillery.

\section{Disbursing Office, Freedman's Branch A. G. O., Saint Louis, Mo., July 27, 1875.}

This is to certify that John Kiernan, farrier United States Army, shod a very heavy horse of mine with his patent Continuous-Calk Shoes on the fore feet, which were worn three months, the horse being used to a family barouch, day after day, and averaging ten miles a day on the roads and streets of Saint Louis, considered a severe test; said shoes are now in possession of Mr. Kiernan, a little worn down but still fit for use.

My horse never traveled freer or appeared more sure-footed in slippery places with any other shoe; but as a matter of economy alone I would recommend this shoe, as all others tried by me have been worn out by this horse in four weeks.

P. T. SWAINE, Lieutenant-Colonel Fifteenth Infantry.

A true copy :

J. Gales Ramsay, Captain Second Artillery.

Satyt Louis Veterinary College axd Hospital, 1114 Lucas Christy Arenue, Saint Louis, December 1, 1875.

To whom it may conecrn :

This is to certify that I have tried Mr. John Kiernan's Continuous-Calk Shoe, on a sorrel horse, the property of the Saint Louis 
Railroad Company, who had been previous to using Mr. Kiernan's shoe nearly always lame from corns, weak feet, \&c. Since shod by the continuous calk he has never been lame, and has worked with satisfaction, traveling an average of 22 miles daily. After using one pair of shoes three months they were but half worn. Mr. Kiernan's shoe has with me no rival. Its natural bearings and equal pressure on all parts of the sole being very desirable to maintain a healthy condition of the feet. For economy and endurance it certainly caunot be equaled; in fact, too much cannot be said of its advantages.

Respectfully,

DR. M. GENETY, Veterinary Surgeon.

P. S.-I have also used Mr. Kiernan's patent on private horses with equal satisfaction.-M. G.

Sworn to and subscribed before me, a notary public within and for the county of Saint Louis, State of Missouri, this 16th day of August, $18 \pi 7$.

[SEAL.]

A true copy:

F. A. JOHANN, Notary Public.

J. Gales Ramsay, Caplain Second Artillery.

Headquarters Army of the United States, Saint Louis, Mo., April 2, 1876.

SIR: I take great pleasure to inform yon that I hold your horseshoe in high estimation; I have used it on a heavy horse during the past year, and during that time the horse's feet have been in good condition, and he at all times has been ready for service.

One peculiar excellence of your shoe is, I think, it furnishes an equal bearing to all points of the shell of the hoof instead of at three points, as in the ordinary shoe.

Very truly, yours,

W. D. WHIPPLE, Brevet Mrajor-General, $U$. S. A.

Mr. John Kiernax, Chief Farrier United States Army, Saint Louis, Mo.

A true copy of a true copy. J. Gales RaMsay, Captain Second Artillery. 
Office Acting Assistant Quartermaster,

Saint Louis Barracks, Mo., Norember 30, 1877.

General: Referring to your communication of October 4, 1877, in relation to John Kiernan's Continuons-Calk Steel Horseshoes, I have the honor to state that the samples of steel shoes sent to your office, with one exception, were made by hand, of cast steel. The exception referred to was made of Bessemer steel, and is so labeled.

This shoe was worn two months on General Whipple's horse. Some of the samples sent, it will be noticed from the labels, were made of iron.

Mr. Kiernan has perfected arrangements with parties in Pittsburgh by which any number of shoes required can be furnished. It is proposed by these parties to manufacture them of crucible steel, this being considered by them as nore suitable than any other material.

Very respectfully, your obedient servant,

S. L. WOODWARD,

First Lieutenant Tenth Cavaliy, A. A. Q. M

The Quartermaster-General U. S. A.,

Washington, D.C.

\section{A true copy: \\ J. Gales Ramsay, \\ Captain Second Artillery.}

Saint Louis Barracks, Mo., January 7, 1878.

General: In reply to your communication of December 13,1877 , referred to me by Lieut. S. L. Woodward, Tenth Cavalry, acting assistant quarternaster at this depot, relating to my improved horse-shoe, I have the honor to inform you that Mr. C. Bidwell, proprietor of the Pittsburgh, Pa., Crucible Stecl-Casting Works, will furnish my improved horseshoe in such quantities as the government may require them at $\$ 13$ per keg of 100 pounds each.

It will be seen by the following that a saving of alout one-third can be made by using my horse-shoe when properly applied.

The Burden shoe per set weighs $4 \frac{6}{16}$ pounds; my shoe 3 pounds per set; making $1 \frac{6}{16}$ pounds less in weight per set. One keg of Burden's horseshoes No. 2,100 pounds contains 22 sets. One keg of my horseshoes of the same weight eontains 33 sets.

I would therefore respeetfully request anthority to visit Washington City, for the purpose of showing the proper application of my horseshoe to the Quartermaster-General, should he order a supply for the depot in that eity for trial. 
I inclose herewith an extract from Mr. Bidwell's letter, dated January '2, 1878.

Very respectfully, your obedient servant,

JOHN KIERNAN,

Chief Farrier.

To the QUartermaster-GeneraL U. S. A.,

Trastingion, D. C.

A true copy :

J. Gales Raisay,

Captain Second Artillery.

[Marked $\left(\frac{1}{4} \frac{1}{37}\right)$ Q. M. G. O., Jan'y 12, 1878.]

Pittsburgh Crucible Steel-Castixg Works, Piltsburgh, Pa., Junuary 2, 1878.

SIR: *** With reference to the price, I wili furnish the shoes to the goverument for good-sized orders at 13 cents per pound net, and would be pleased to receive their orders.

Yours, \&e.,

J. C. BIDIVELL.

Mr. Kiervan,

Chief Farrier, U. S. A., Saint Louis, Mo.

A true copy of a letter transmitted by the Quartermaster-General:

J. Gales RaMisay,

Captain Second Artillery.

[Marked (1546) Qr. Mr. Gen'l's Office. Rec'd Mar. 19, 1878.]

Shoexberger \& Co., Juniata Irox Works, Pittsbuigh, Mareh 18, 1878.

Dear SIR: Our Juniata horse and mule shoes were recommended for the use of the government by the Board of officers that sat in Philadelphia two years ago. Lately we have introdnced an improved shoe, which we call the "Roadster" pattern, the merits of which are fully set forth in the catalogue we send you by same mail as this. We sent you samples by express on the 16th instant of this style of shoe. The iron is uniformly unexceptionable in quality, and we hope on examination you will feel justified in recommending it for Army use.

Very respectfully, your obedient servant,

General M. C. Meigs,

SHOENBERGER \& CO.

Quartermaster-General U. S. A., Washington, D. C.

A true cops :

J. GaLes Ravisay,

Captain Second Artillery. 
[Marked (4362) Q. M. G. O. Rec'd Sept. 22, 1877.]

Depot QUnitemister's OfFrCE,

Trashington, I. C., september 21, 1877.

GeNeral: The samples of horseshoes received from the Rhode Island Horeshoe Company, through Mr. Augustus Seeley, have, by your direction, been subjected to a fair trial. In reference thereto I respectinlly reported as follows:

The shoe is lighter and of softer material than that of the Perkins or Burden manufacture. It is thickest at the toe, where subjected to the greatest wear. The nail-holes are more deejly countersink than in any other shoe I have seen, and in the trial made the shoe holds its place firmly till worn very thin, while the hoof is kept in a good state of preservation. It is, in my judgment, a good shoe, and well adapted to the public service.

The low price at which it is offered is worthy of attention. The report of the veterinary surgeon* is inclosed for the information of the Quartermaster-General.

Very respectfully, your obedient servant,

$$
\begin{aligned}
& \text { A. F. ROCKWELL, } \\
& \text { To the QUat Quartermaster. } \\
& \text { Deftermaster-General of THE ARMY. }
\end{aligned}
$$

A true copy:

J. GALES RAMSAY, Captain Second Artillery.

\section{Depot Quartermaster's Corral,}

Whashington, D. C., September 12, 1877.

SIR: About two months past a keg of Seeley Horseshoes were sent to the corral for trial. They have had a fair test with the other kinds of shoes. They need little alteration in shape to fit a horse's foot. 'The quality of the iron is such that they can be fitted cold. The nail-holes are well comutersunk, so that the shoe sticks on till worn out. The greatest substance is where the most wear is (viz, at the toe). For the last two reasons, although not as heavy as most other machine-made shoes, they outwear them. There is no system of mutilating the foot attached to the use of them. The nails which aceompanied the shoes are of good shape and quality.

For the above reasons I have the honor to report that they are a good horseshoe.

I am, sir, very respectfully,

\section{JAS. BUSHMAN,} Veterinary Surgeon.

Colonel Rockwell,

Depot Quartermaster.

A true copy :

J. Gales RaMsay, Captain Second Artillery.

*This is the report above referred to. 
[Marked (5077) Q. Mr. G. O. Ree'd Oct. 31, 1877.]

Providexce, Oetober $30,1877$.

Sir: On the 10th of September last I sent through Mr. W. S. Skinner, of 410 and 412 Commerce street, Philadelphia, to the United States Arsenal, Gray's Ferry, Philadelphia, samples of Seeley horseshoes and Seeley nails, for trial, and advised General J. J. Dana, assistant quartermaster-general, Philadelphia, of the same. Will you please send me his report on them, and oblige,

Yours, truly,

\section{AUGUSTUS SEELEY,}

Care Rhode Istand Horseshoe Company, Providence, R. I.

To General M. C. Mergs,

Quartermaster-General U.S.A.

A true copy :

J. GaLes Ramsay,

Captain Second Artillery.

[First indorsement.]

Respectfully referred to Col. D. H. Rucker, assistant quartermaster-general, U. S. A., in charge of Philadelphia depot of the Quarternaster's Department, Philadelphia, for report.

I. C. MEIGS,

Quartermaster General, Brevet Major-General, U. S. A.

A true copy:

J. GaLes Ramisar,

Captain Second Artillery.

[Second indorsement.]

Respectfully referred to Maj. J. J. Dana, quartermaster, U. S. A., with the request that he will please furnish the report called for in the Quartermaster-General's preceding indorsement.

\section{H. RUCKER,}

Assistant Quartermaster-General, U.S. A.

A tme cops :

J. GaLEs Raursay,

Captain Second Artillery.

[Third indorsement.]

QUaRTERMaSTER's OFFICE,

Philadelphia, Norember 3, 1877.

Respectfully referred to Capt. John F. Rodgers, M. S. K., who will please report his opinion of these articles, if they have had sufficient trial on the public horses at Schuylkill arsenal.

\section{J. J. DANA,}

A true copy:

Major and Quartermaster, U. S. A., Clothing Depot.

J. Gales Ramisay,

Captain Second Artillery. 


\section{2}

[Fourth indorsement.]

Philadelphia Depot of the

QUARTERMASTER's DEPARTMENT, Philadelphia, November 5, $187 \%$.

Respectfully returned to Maj. J. J. Dana, in charge clothing depot. The horseshoes referred to have been tried on the public animals of this depot. They appear to be a good pattern and quality, but are not suited to cobblestone streets. They might prove acceptable on macadamized or soft roads; they are evidently designed for such service.

A true copy:

JOHN F. RODGERS, Capiain and M.S. K., U.S. A.

J. Gares Ramisay,

Caplain Second Artillery.

[Fifth indorsement.]

QUARTERMASTER's OFFICE,

Philadelplia, Norember 5, $187 \%$.

Respectfully returned to Col. D. H. Rucker, assistant quartermaster-general, U. S. A., inviting attention to the fourth indorsement hereon. The number of horses at this depot is insufficient for an extensive trial of the horseshoes referred to herein.

An opinion of their merits can be better obtained from use in the mounted service.

A trie copy:

J. GALES RAMSAY,

Captain Second Artillery.

[Sixth indorsement.]

Philadelphia Depot of

QUARTERMASTER'S DEPARTMENT,

Philudelphia, November 6, 1877.

Respectfully returned to the Quartermaster-General U. S. A., and attention invited to the indorsements hereon (the fourth and fifth) by Capt. John F. Rodgers, M. S. K., and Maj. J. J. Dana, quartermaster, U. S. A.

A true eoly:

D. H. RUCKER, Assistant Quartermaster-General, U.S. A.

J. GALES Raysay,

Captain Second Artillery.

[Note, General Meigs, Jan. 29, 1878.]

Mexr.-Does the Washington and Georgetown Railway continue use of Goodenough shoe? Does it still set shoes cold?-M. C. M.

Colonel ROCKWELL. 
Reply.

Gexerıl: Mr. Hurt, president Washingtou and Georgetown Railway, informs me that the Goodenough shoe was nsed by their company from June 1 to October 15,1877 , when it was abandoned on accomnt of dissatisfaction. I have questioned several of the drivers regarding the Goodenongh shoe. Their testimony was miformly and emphatically unfavorable.

The Seeley shoe and nail was sulstituted on October 15, 1877. Mr. Hurt reports that they give great satisfaction. The shoe is set cold; it is light and durable.

$$
\text { JAXYARY 30, } 1878 .
$$

A. F. ROCKWELL.

A true eopy:

J. GALES RAMSAY,

(aptain second Artillery.

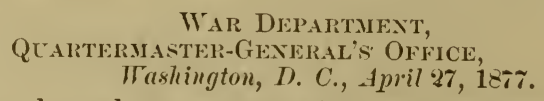

The following notes on horseshoes are respectfully communicated as of interest to the service.

$$
\begin{gathered}
\text { M. C. MEIGS, } \\
\text { Quartermaster-General, Brecet Major-General, L. S. A. }
\end{gathered}
$$

$$
\begin{gathered}
\text { War Departuent, } \\
\text { Quarternaster-Gexeral's OFFlCe, } \\
\text { Washinglon, D. C., April 18, 18т\%. }
\end{gathered}
$$

Gexeral: In obedience to rour instructions, I proeeeded on the 9th instant to New York City to make inquiries as to the horseshoes used in that city by the' varions stage, street-('ar, and express eompanies.

I first visited the office and shops of the Second Avenue Company. This company uses the Goodenough shoe. It began using it only a few months ago. The president of the eompany informed me that every director in the company was opposed to its introduction, feeling assured the feet of the horses wonld be rnined, but he insisted mpon giving it a trial, feeling himself assured it was better and cheaper than any other shoe.

The president informed me that the experiment was successful; that the feet of the horses had improved; that all opposition to the shoe, on the part of the directors, had disappeared, and the directors were now strongly in favor of it and sustained his course in

\section{$3 \mathrm{H} \mathrm{S}$}


introdueing it. The president sait that in the item of shoeing there was a saving to the company yearly of from $\$ 10,000$ to $\$ 13,000$. The company contracts with the Goodenough Conpany to do its shoeing. 'The shoes are put on cold. I saw the work in operation. The foot was quiekly prepares by a little cutting with a knife and then pared down by a rasp. The president of the company said the horses were scarcely ever lame by being "pricked" in shoeing since the adoption of the new system. This, if clue to the system, is an important matter. Pricking of horses in shoeing lays a horse up for a long time.

There is no doulut but what the Second Avenue line is a firm advoeate of the Goorlenough horseshoe and of the method of shoeing adopted by the Goodenough Company. The president of that line used strong language in reference to the shoe; that he would consirler it economy to use the Goodenongh shoe and pay for it, if he even got the other shoes without paying for them. The company has about 1,125 horses at work.

I went next to the stables of the Madison Avenue stage-line. This line uses the Goodenongh shoe, and has nsed it for some time. I was informed that the shoe gave entire satisfaction. Here the shoeing is done by the company and fire is used. The shoes are all provided with a toe-clip before being put on. The object of the clip is to prevent the shoe from slipping, and takes off some of the strain from the nail. The eompany has some 300 horses in use.

I then visited the stables of the Fifth Arenue stage-line. This line also uses the Goodenough shoe and does its own shoeing. It also uses fire in shoeing, and has the toe-clip. The overseer said the shoe in use gave satisfaction; was strong and durable, and protected well the feet of the horses. Their line has some 400 horses.

I then visited the shops of the Sixth Avenne Railroad Company. This is one of the large companies of the eity; has some 1,300 horses. I found in the shops nine fires. The Goodenough shoe is not used at all. Both the Burden and Perkins shoes are nsed, more of the former than the latter. The shoes are prepared with clips on the side as well as on the toe. The foreman of the shop had deeided objection to the Goodenough shoe. He said it was too light, not thick enongh at the heel, the web not wide enough, and the punching of the shoe for the nails not done at the proper places. He was strong in his condemnation of it. The shoes in use were much heavier than in the other shops I had visited, and looked more clumsy. They had both toe and heel calks. The foreman considered the Burden and Perkins shoes as among the best in the land. He also spoke favorably of the Shoenberger shoe. This shoe is made in Pittsburgh, Pa., and was well spoken of by the Board in Philadelphia which investigated the subject of horseshoes for the Army.

I then went to the Broadway and Seventh Avenue Railroad shops. This company is a large one, employing some 1,250 to 1,300 horses. The superintendent went with me to the shop where the horses are shod. The Burden shoe is extensively used. A supply of that shoe 
had just been laid in, previous to which the Perkins shoe had been in use. The price of the Burden was a little less than the Perkins which seemed to be the reason the Burden was bought. Both these shoes are well thought of by the superintendent. He regards them as the best the company could buy. He was not in favor of the Goodenough shoe. Had tried a few of them and did not like them. Had about the same objections to them that the foreman of the Sixth Avenue line had. The shoes used here are fitter with toe-clips and also side-clips.

I then visited the shops of the Eighth Avenne line. This is a large company, employing from 1,100 to 1,200 horses, and runs the cars on the Ninth Avenue. Some of the horses on the Ninth Avenue are being shod with the Goodenough shoe, but the shoe in general use on the Eighth Avenue is the Burden. The foreman told me it gave him satisfaction-was strong and durable. He was not in favor of the Goodenough shoe.

I then went to the office of Dodd's Express and Transfer Company. In this company the Goodenough shoe is exclusively used. I was told that it had been used for a long time and was preferred to any other shoe. It was proved to be durable, and perfectly protected the feet of the animals. The company has some 475 horses in use, and it has some heavy hanling.

The Fourth Avenue Railroad Company was next visited. The Goodenough shoe is not nsed at all. The superintendent said to me that he thought well of the shoe, but the president of the company did not like it, and so it was not used. The superintendent thonght that with the Goodenough shoe he could do the shoeing with eight men, where he is now working twelve. The shoe in use is principally the Burden. There are some 900 horses in use.

The Third Avenne Company does not use the Goodenough shoe. It prefers the Burden and Perkins.

Adams \& Co. Express use the Goodenough shoe exclusively. It has a great deal of heavy hanling and employs some 200 horses.

The American Express Company uses the Goodenough shoe exclusively, and also supplies that shoe to all its oftices throughout the country. I think, though, the Buffalo office must be an exception, unless the shoe has been sent there since January, 1876. At that time I talked with the superintendent of the company in Buffalo about the Goodenongh shoe, and found he did not like it; that he had given it $u p$ after quite a trial. He was then using a handmade shoe. I think it doubtful, however, if any company could afford to use, to any extent, hand-made shoes. The expense would be too great.

The Belt Line Railroad in New York uses the Goodenough shoe, and its shoeing is done by contract.

The Two Hundred and Thirty-sixth Street Stage Company also uses the Goodenough shoe, and has for some time.

The above are the principal lines of street cars, express companies, and stage lines in New York. There are a few other crosstown lines, but I did not have time to visit then ; indeed, I did not think it necessary to do so. 
From what I saw I coneluded that the Burden, Perkins, and Goodenough shoe has each its followers, and that each shoe has merit; that the purchase of shoes for the ear-lines of New York is mostly in the hands of the superintendent and foreman of the lines, regard being had of course to the price, and that their likings or dislikings govern as a general thing; and that the action of a Board of Officers convened at Philadelphia to investigate the subject of horse and mule shoes for the service, and which is published in General Orders No. 7 , of 1876 , is wise, practical, and should be adhered to.

Very respeetfully, your obedient servant,

HENRY C. HODGES,

Deputy Quartermaster-General, $U$. S. A.

To the QUartermaster-General, U. S. A.,

Wrashington, D. C.

The recommendations of the Board of Officers convened by paragraph 3, Special Orders 264, W. D., A. G. O., December 27,1875 , in its report on the subject of the horseshoes and mule shoes best adapted for the service, which was approved by the Secretary of War and published in General Orders No. 7, W. D., A. G. O., of 1876, are as follows:

For the Cacalry service, the iron Goodenough horseshoe; also, when specially called for, the Burden and the Shoenberger horseshoes.

For the Artillery service, the Goodenough horseshoe, both iron and stcel, the Burden and the Shoenberger.

For team horses and mules, the Goodenongh horseshoe, both iron and steel, the Burden and the Shoenberger.

$$
\begin{gathered}
\text { War Departuent, } \\
\text { Quarternaster-GeNeral's OFfice, } \\
\text { Washington, April } 25,1878 .
\end{gathered}
$$

Official :

HENRY C. HODGES, Deputy Quartermaster-General, $C$. S. A.

\section{WAR Departuent, QUARTERMASTER-GENERAL'S OFFICE, Washington, D. C., May 16, 1878.}

CAPTAIN : I am directed by the Quartermaster-General to inform jou that this office has two other patterns of horseshoes to submit to the Board for examination and report-one the patent of John D. Billings-which will probably be all that will be submitted, and 
to request that yon advise this office when the Board will be ready to receive them.

Very respectfully, your obedient servant, HENRY C. HODGES, Deputy Quartermaster-General, U. S. A.

Capt. F. B. Haviltox, Seconil Artillery, President Board on Horse and Mule Shoes, Washington Arsenal, D. C.

(2026, Q. M. G. O., 1878. Filed with 1174, Q. M. G. O., 1877.)

A true copy :

J. GaLES RaMisay,

Captain Second Artillery.

\author{
War Departuent, \\ Quartermaster-GeNeral's OfFice, \\ Treshington, D. C., May 20, 1878.
}

CAPTAIN : I am directed by the Quartermaster-Greneral to acknowledge receipt of your letter of the 1 sth instant, stating that the Board will meet at the Washington Arsenal this date, and to submit herewith one set of Henry C. McCeney's Patent Horseshoes and twelve samples of John D. Billings' Nachine-rolled Horseshoes, and a sample of the iron of which made, together with the papers on file here relating to these two patterus of horseshoes, and to request that yon arlvise this office by bearer when the Board will be ready to take up for examination the Billings Horseshoe, as Mr. Billings, whose address is 265 Broalway, New York City, desires to be present at that time and put on the shoes for a number of horses. Very respectfully, your obedient servant,

HENRY C. HODGES,

Deputy Quartermaster-General, $C$. S. A.

Capt. F. B. Hanimtox, Secomid drtillery,

President Board on Horse and Mule Shoes,

Wrashington Arserat, Washington, D. C.

(2260, Q. M. (.. O., 1378, 2 inclosures ; 2603, Q. M. G. O., 1878, 2 inclosures; 2026 , Q. M. G. O., 1-7=, filed with 1174, Q. M. G. O., $137 \%$ See 415 , of 10,8 , therewith.)

A true copy:

J. Gales Raysay,

Captain Second Artillery. 


\section{War DepartMent, QUartermaster-GeNeral's OFFICE, Washington, D. C., May 24, 1878.}

Captain: I am directed by the Quartermaster-General to send you herewith, for the nse of the Board, two additional sets of horseshoes and one set of mule shoes, the patent of Henry C. McCeney, the papers in regard to which were submitted to the Board by this office, with one set of the horseshoes, on the 20th instant.

Very respectfully, your obedient servant,

\section{HENRY C. HODGES,}

Deputy Quartermaster-General, U.S. ${ }_{-}^{-} A$.

Capt. F. B. Hamlton, Second Artillery, President Board on Horse and Mule Shoes, Trashington Arsenal, Washington, D. C.

2260, Q. M. G. O., 1878.

A true copy :

J. Gales Raysar,

Captain Second ditillery.

[2260, Q. M. Gen.'s Othice. Rec'd April 24, 1878.]

Washington, D. C., April 23, 1878.

SIR : I have the honor to submit for your alproval one set of my new Non-interfering Horseshoes; also, a copy of letters patent (No. 199302 , as rendered in the records of the United States Patent Office) issned January 15, 1878, respectfully reqnesting, upon your approval, that yon will submit the same to the Board now in session for the selection of a horseshoe for the United States Army, that they may praetically test its merits.

I think this shoe will not only be of benefit to myself, but also to the United States Army.

Respeetfully,

H. C. MCCENEI, 901 Pennsylienia Aremue, City.

QUartermaster-General, U. S. A.

A true copy:

J. Gales RamsaY,

Captain Second Artillery. 


\section{LETTERS AND RECONMENDATIONS.}

\section{HOWARD'S PATEN'T HORSESHOE.}

Mr. E. B. HUBBARD,

The EBbitt,

Washington, D. C., July 19, 1878.

\section{Recorder, \&c. :}

I send you some letters which I respectfully request may be laid before the Board of Army officers of which you are recorder. One is from Mr. J. W. McCarty, a well-kuown and large contractor; one from Col. E. B. Pickett, mining engineer; one from J. H. Hajes, practical blacksmith; one from William Willis, practical blacksmith ; one from S. MI. Hickey, the largest ice-dealer in Saint Louis, and one from Dr. S. I. Tutt, a well-known and leading physician of Saint Louis County. All of these persous are well known and men of standing, and all are practical men. I shall send some other letters in a few days.

I shall be glad to furnish the Board with more shoes should more be required.

Very respectfully, your obedient servant,

MARCUS J. WRIGHT, 800 Tenth Street, Northeast.

KIRKWOOD, June 14, 1878.

Dear SIr: My horse was shod about 20th November, 1377 , with the shoes known as the Howard Improved shoe, and althongh the horse was in constant use, they remained on, entire, for a period of over three months, giving great comfort to his feet, the condition of which had always been a difticulty before that. I consider it the best shoe, in every respect, I ever saw, and believe it will not fail to supersede the kind now in nse.

Very respectfilly,

Colomel Howard.

S. I. TLTT, M. I.

I an still usiug the shoe, and expect to do so, solung as it is as conrenient, or "ren less so, to obtain them ans the common shoe.

OFFICE OF S. M. HICKEY \& CO., WiIOLARAle ICE Dealers, Saint Louis, June 15, 1878.

Dear Sir: Yours at hand making inquiry as to how your improved horseshoe worked on our horse, de. I have no hesitation 
in saying that I think them the best shoe I ever saw. We have used them on a pair of driving horses, and they worked splendidly; they are less liable to slip with your shoes than any other that we have used, and seem to be very easy and a good wearing shoo. The rope in the cavity seems to act as a cushion and furnishes elasticity. I think it almost impossible to improve on them. We intend to use them on all of our horses in future.

Yours, truly, \&c.,

S. M. HICKEY.

J. R. Howari, Esq.

Horse-Sholing Establishumext, 1603 Market street, Saint Lonis, June 16, 1878.

Mr. Howari): I have tried your Patent Shoe on three of my customer's horses ; they have given entire satisfaction in every way. They give the horse a sate and elastic step on our hard and slippery streets. For buggr, saddle, and light draught horses they cannot be surpassed, and when hetter known will be more appreciated. Respectinlly, yours.

WM. WILLIS, I'ractical Blacklsmith.

SAINT Lotis, June 12, 1878.

DEAR SIR: I liave in taily use a finll set of Howarl's Improved Horseshoe, and I take pleasine in saying they give entire satisfaction to myself and horse. Properly made and weld arljusted to the foot, I camot conceive of any improvement on them.

Respectfilly,

J. IV. C'LARKE, Esip.

EI). BLRKE PICKE'T'T, M. E.

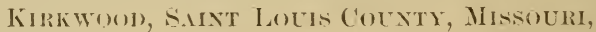

$$
\begin{aligned}
& \text { A)ril } 20,1 \text { - }
\end{aligned}
$$

DEAl: S1: I am a practioal hlacksmith, and have shod several horses with the Howatrol Improved Horseshoe, and they hare given great satisfartion to my customel's; in tact, they will now nse no other shore. They wear longer than the old-fashionerl shoe, and have a good soft spring to the loose on om hard rock roarls. They are in "very way, in my opinion, betfer than the old shoes. So suro am I of that fivet, that I haveapplied for the ageney of this comuty, as $I$ am certain there is not a man in the comnty who tries them once will use any other horseshoe.

linejrecttinly, yours,

To I. 'THPleTr, Esq.,

J. II. IIIIES.

Suint Lonis. 


\section{Lime axi Cemext Wakemogat, Samt Lovis, Mo, June 8, 1873.}

DEAR Sir: In reply to your faror of resterday, asking me how I am pleased with the Improverl Horseshoe, and how it works on my horse, I take pleasure in saving that they are the best shoes I have ever used on my horse. I an a enntractor; and my horse is in use every day, doing hard work, rer since your shoes have been on him. They have worn longer by a loug way than any shoe that has ever been on him; he never slips now, and keep his hoofs in splendirl condition; in every way he moves easier and with confidence. It is now two monthis since I put them on him, and, from their lonks, will wear two weeks longer. I want no better shoe for my horse, and ean safely recommend them to all horse-owners as the best anrl safest shoe in use.

Yours, truly,

JaMES R. HOWARD, ENis.

\section{J. W. MCCARTY.}

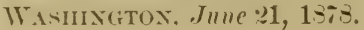

Sir: I inclose letter from Mr. Wr. W. Fenton, which I respeetfully recinest may be laid hefore the Board of Army officers appointed to test and report unom horseshors, of which you are recorder.

Mr. Fenton is a gentleman of standing and character, ancl made, as you see hy his letter, a very thorough test of the shoes.

I an, sir, very respectfilly, your obedient servant,

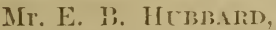

MARCIS J. WRIGHT.

First Lientenant second Artillery.

THE MeIKES Nersertes COMPAXY, Vorth Bristol, Ohin, June 17, 1878.

DEAR SIr: In reply to your inquiry, I state I harl a pair of the Howard Patent Horse shoe put on my lougey-horse aud cluove him almost every day on an a verage of 20 to 25 iniles over rock roads in Saint Louis Cominty, Missonri. The shoes remained on him some ninety days, and improved his feet and action. I regard them as the best shoes I ever nsed.

Yours, truly,

General Marcés J. Wrighit,

W. W. FENTON.

Washington, D. C. 
House of Represextatives,

Washington, D. C., June 13, 1878.

Mr Dear Sir: I inclose yon letter from ex-Governor Shepherd, which I respectfully request you to lay before the board of which yon are secretary.

Very respectfully, your obedient servant,

Lieut. E. B. Hubbard,

MARCUS J. WRIGHT.

second Artillery, Fort MeHeury.

OFFIC OF AlEx. R. SIIEPIIERD,

IVashington, D. C., June 12, 1878 .

MY DEAR SIR: I have nsed with great satisfaction the Howard Patent Horseshoe, and an convinced of its great merit, and that it is a decided improvement upon any shoe $I$ have ever seen. For large horses it is a great relief, and will benefit any horse inclined to tendemess in feet or legs. I hope they will be adopted by the Army.

Very respectfully,

Lient. E. B. Hubbard,

ALEX. R. SHEPHERD.

First Lieutenent second Artillery, I. S. A.

No. 800 Texth Strext, NoRtheast, Washington, I). C., June 10, 1878.

DEAR Sir: I inclose for reference to the Board of which you are recorder a letter from Hon. Balie Peyton, of Tennessee, former member of Congress and United States minister to Pern, and also a letter trom Mr. James C. Saunders, clerk to the Committee on Ventilation House of Representatives. Colonel Balie is one of the oldest and most distinguished tnrfinen in the United States, whose opinion in all matters relating to horses receives and is entitled to the greatest resper $t$.

I shall have several other letters from residents of Washington and Saint Louis, which I will forward you in a few tlays.

I am, sir, very respectfinlly, your olectient servant,

Mr. E. B. ILUBbard,

MARCI'S J. WRIGHT.

First Lientenunt Seeond Artillery, Recorder of Boord.

TIIE EnBitT,

Tashington, D. C., June 8, 1878.

DEAR SIR: The How ar l Patent Horseshoe is a shell of either malleable iron, wrought iron, or cast steel ; those on oxhibition here now being of malleable iron, the shell is filled with tarred rope, treated and put in, under a heary pressure. 
The peculiar adjustment of the nail-holes prevents pricking, and yet fastens the shoe securely; the roughened or corrugated base, on which the hoof rests, canses the hoof to fit on closely, and prevents gravel, soil, or water from reaching the foot. The tarred rope acts as a cushion and prevents concussion, stoving, "slips," and straining of the limbs.

The base of the shoe is very wide and the frog of the foot is given full play. These are some of the rirtues, which strike me, that recommend this pattern of a shoe to universal adoption. Many of the properties of this shoe supply wants long needed, and a preventative to many abuses to which horse-flesh has heretofore been subjected.

It may not be inappropriate for me to state that my experience and observation of the subject-matter of this letter is as great and varied perhaps as any gentleman's in this country. I have bred many fine horses and have had occasion as well as an inclination to pay particular attention to the hoof and manner of shoeing horses, and my convictions are thorough and replete that this shoe is the best I have ever seen to supply the protection so much desired.

I am, very respectfully,

\section{Lieutenant HCBBard, Secretary of the Board.}

BALIE PEYTON, Tennessee.

Wasmingtox, D. C., June 10, 1878.

DEAR SIR: In reply to your letter of this date, inquiring ras to my opinion of the Howard Patent Horseshoe, I will state that the set of shoes furnished by you and put on my trotting horse have given the greatest satisfaction. The shoes are well fitted and firm on the hoofs; the horse has free action, does not slip, and travels with great ease.

Yours, very truly,

General Marces J. Wright,

JAS. C. SAUNDERS.

Washington, D. C.

Washisgtox, May 22, 1878.

Mr Dear Colosel: Referring to the conversation we had this morning in regard to the strength of the Howard Patent Horseshoes, now on trial before a Board of Army officers in this city, I beg to say that the shoes submitted to that Board were rudely and rather hastily manufactured, by the only malleable iron works in Saint Lonis, and that my limited ineans wonld not permit me to have the work done by older and better estahlishments. I am assured by manufacturers in Philadelphia, Chicago and Worcester, Mass., with whom I have been in correspoulence on the sulject, that they can 
manufacture these shoes so that they will stand any pressure necessary to ehange their shape, without impairing their strength. Colonel Howard, the inventor of these shoes, submitted them to Dr. Benuett, who (I am informed) is a very distinguished veterinary surgeon of London, and he wrote Colonel Howard: "I regard malleable iron as the best material for horseshoes (except for some purposes where steel would be preferred), aud the filling of rope in vour shoes atfords a protection to all classes of horses, and particuiarly those whose service requires travel over hard roads, not offered by any shoes I have ever seen.

"In regard to sizes, I think that five sizes for round-footed horses and five for narrow-footed ones, marle in strict conformity to the horse's foot, as these appear to be, will fit all horses whose feet are not deformed; or if they do not precisely fit, the change necessary to be made will be so slight, that it will require but little pressure."

The shoes sulmitted to the Board here were all for round-footed horses, as we harl no models for the others, and several sets had to be altered to such an extent that it no doubt impaired their strength; bnt with all the sizes preparerl and made of the best material, I am sme that no ohjection will be fomcl on aceount of want of strellgth.

Of the several hmolred sets used in Saint Lomis within the past eight months, very tew ever broke in use, and they did not fail, in a single instance that I an aware of, to give entire satisfaction, and the test was extended to animals in all the sorts of service in the city.

$$
\text { Very tunly, your friend, }
$$

Col. R. T. Wintersmiti.

\section{MARCUS J. WRIGHT.}

These shoes can be made of cast steel at an arlitional cost of about 3 cents per pomml. Please submit this communieation to the Army Boarcl.

WAsmisgtos, April 12, 1058.

Gextlinex of tue Army Bo.dro: I make the following-named claims for the Howarl Patent Horseshoes, which are snbmitted for your examination: That they nit the hoof more perfectly than any other shoe; that they prevent slipping, straining, bucking, and crackod heels, and that they enre temler-foot; that they can be put on by any smith, or, if necessary, by auy person not a smith ; that ther wear longer than any shoes now in use; that the nails aro adjusted that a horse cannot be pricked in shoeing, and that the nails, being forcer into the hard part of the hoof, and the string of tarred rope pressed into the (outer) nail-groove to set the nails tirmly, that they hold more firmly than any other shoes; that the corrugations on the npper surface of the shoes indent themselves 
into the hoof in a few days, preventing sand, gravel, or even water from reaching the hoof. The theory on which these shoes are constructed is, that a horse, to have proper action, must stand level, and comsequently in a natural position; that the hoof should not be trimmed, except to make the lower surface smooth; that the frog must not be cut array on the outside, or enamel filed off.

Respectfully,

MARCUS J. WRIGHT.

\section{LETTERS AND RECOMMENDATIONS.}

\section{BILLINGS PATENT MACHINE-ROLLED HORSESHOES.}

North Hero, Vt., July 15, 1878.

Gexrs: I herein acknowledge the receipt of the four shoes I ordered some two weeks ago. Nif opinion of them is that they are the most perfect horse-shoe I ever saw. I am very mnch pleased with them. The ease with which my old, bunged-np, thirteen years old horse travels off with is evidence enough to me that they are the shoe.

Yours, truly,

The Johy D. Billings Patext Horseshoe Conpayy,

New York.

The John D. Billings Patext Horseshof Conpaxy,

No. 265 Broaduay, New York, July 2, 1878.

DEAR SIR: We inclose you a letter just received from a gentleman who has tried onr shoe. Believing this will aid you in forming an opinion of its merits,

We are, very respectfully,

Tine John D. Billings Patent Horsesilok Company,

WM. L. FLEMING,

Capt. F. B. Hamilton, U.S.A.,

Treasurer and Secretary.

"Tashington, D. C.

Catawissa, Pa., July 1, 1878.

GExTs : Inclosed please find $\$ 2$, for which please send me two sets of your patent horseshoes, as follows: One pair front shoes, 5 inches ; 1 pair front shoes, $5 \frac{1}{4}$ inches ; one pair hind shoes, $4 \frac{8}{4}$ inches; one pair hind shoes, $4 \frac{1}{2}$ inches. I have one set on one of my horses, and, so far, like them very much. My other horse not needing shoeing at the time, I let a doctor have the one pair, and he 
likes them, and thinks they are the best shoe out. I want to try one pair on a tender-footed horse, and if they give satisfaction on him, I think that will establish a little tracle here, so that either the blacksmith or myself will order a small lot, \&c. Send the same as before, and oblige,

Yours, very respectfully,

J. H. GEARY,

Catawissa, Columbia County, Pennsylvania.

J. D. Billings Patext Horseshoe Company,

265 Broadwely, Tew Tork.

Washingtox, D. C., June 24, 1878.

GENTLEmen: I like your shoe. After a tair trial, I pronounce it a success. I believe its nuiversal adoption only a question of time. The best I can say is, that my customers who use it once come back after them again.

Very respectiully,

M. HARRIGAN,

Hoiseshoer, No. $615 \mathrm{~B}$ street, N.W.

John D. Billings Horseshoe Compaxy.

Wasmingtox, D. C., June 18, 1878.

DEAR SIR: After a fair and satisfactory trial of your Patent Horseshoes, I can tully concur with the above statements of the worth and value of the said shoes. I cau pronounce them perfect ease and comfort to all classes of horses, and would recommend them to all owners of horses.

Yours, respectfully,

\section{N. L. FOWLER,}

Hood and Coal Dealers,

Ninth and $G$ streets southeast, Washington City, D. C.

J. D. Billixgs, Esq.,

265 Broadicay, New Fork.

\section{Washington, D. C., June 26, 1878.}

DEAR SIR: In reply to yours of the 17th instant, inquiring my opinion of your shoe, I can only say that I have tried them, and with very satisfactory results, on the principle which they are constructed, I think is the right one; at least they have proven so with one of my horses. 
I have been engaged in the livery business for several years, and I have never nsed a shoe with better results when properly applied.

Yours, with respect, BENJ'N. COOLEY, J. D. Billixgs, Esq. No. 714 E Street, southeast.

Providexce, June 7 , 1878.

SIR: What are your prices and terms for shoes? I have a set on one of my hor'ses, and like them very much. I am traveling through the country, and all that have seen the shoes like them very much. I think that I can introduce them extensively if you wish me to. Yours, respectfully,

Mr. Billings.

E. N. PERRIN.

The John D. Billings Patext Horseshoe Compaxy, No. 265 Broadway, New Fork, June 20, 1878.

DEAR SIR: Thinking that the opinious of persons who have used our shoes for various purposes may be acceptable to you, as they (the shoes) are now being tried on a few of the governinent horses, we inclose a copy of a letter received from a gentleman in Troy, N. Y. (the original on file at our office), who has tried the shoes for some weeks past.

Very respeetfully, yours,

The Johy D. Billings Patext Horseshoe Compayx,

WM. L. FLEMING.

Treasurer and Secretary.

Capt. F. B. Haniltox,

Washington Arsenal, Washington, D. C.

Office of Jayes P. Gates, Dealer ix Coal, No. 89 River Street, CorNer of DivisioN, Troy, N. Y., June 18, 1878.

DEAR SIR: I take great pleasure in acknowledging the reeeipt of some of your patent horseshoes with continuous calk, which I have used some two and a half mouths to my entire satisfaction. They are certainly the most perfect shoe ever used in my stable. They are adapted to all kinds and conditions of horses' feet, and, if properly adjusted, will prove one of the greatest blessings ever offered the American public.

Yours, very truls,

Johx D. Billixgs, New Fork. 


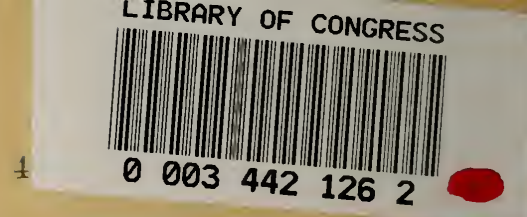

New Yolk, June 17, $18 \% 8$.

DEAR SIR: I have used the shoes I obtained fiom you on a mare who has tender feet, and find they work arbmirably. She now places her feet square on the gromnd, and has improved in her gait. The shoes are the best for all pmrposes I have scent.

Truly, yours,

J. D. Billixgs, Esq.

A. VREDENBURGH.

Original letter on file at on office, 26:5 Broalway, New York City. Mr. Vredenburgh is deputy receiver of taxes New York City, mnder General Martin.

T. MACMAHON.

The Johy D. Bhlixgs Patext Horseshon Company,

To. 265 Broaduay, \ew York, June 18, 18\%?.

DFAR SIR: We herely inclose copy of letter receired hy us from Mr. Alfred Vredenburgh, deputy receiver of taxes of New York.

Mr. Vredenburgh is a horse-fancier, and has had many years of experience as an owner of tine stock.

Your's, very respectfully, Per T.

J. D. B. Pat. Horseshoe Compaty,

Capt. F. B. Hamiltox,

IV teshington disenal, D. C.

0 